\title{
NEW AZO-SCHIFF BASE DERIVED WITH Ni(II), Co(II), Cu(II), Pd(II) AND Pt(II) COMPLEXES: PREPARATION, SPECTROSCOPIC INVESTIGATION, STRUCTURAL STUDIES AND BIOLOGICAL ACTIVITY
}

\author{
ABBAS ALI SALIH AL-HAMDANI I,*, ABDEL MAJID BALKHI², AHMAD FALAH², SHAYMA A. SHAKER, \\ ${ }^{\prime}$ Department of Chemistry, College of Science for Women, University of Baghdad, Iraq \\ ${ }^{2}$ Department of Chemistry, Faculty of Science, University of Damascus, Syria \\ ${ }^{3}$ Departament of enviromental engineering, komar UNiversity of Science and technology, Sulaymani, Kurdistan, Region, Iraq
}

\begin{abstract}
The coordination ability of the azo-Schiff base 2-[1,5-Dimethyl-3-[2-(5-methyl-1H-indol-3-yl)-ethyl imino]-2-phenyl-2,3-dihydro-1H-pyrazol-4-ylazo]-5hydroxy-benzoic acid has been proven in complexation reactions with $\mathrm{Co}(\mathrm{II}), \mathrm{Ni}(\mathrm{II}), \mathrm{Cu}(\mathrm{II}), \mathrm{Pd}(\mathrm{II})$ and $\mathrm{Pt}(\mathrm{II})$ ions. The free ligand (LH) and its complexes were characterized using elemental analysis, determination of metal concentration, magnetic susceptibility, molar conductivity, FTIR, Uv-Vis, (1H, 13C) NMR spectra, mass spectra and thermal analysis (TGA). The results confirmed the coordination of the ligand through the nitrogen of the azomethine, Azo group (Azo) and the carboxylate ion with the metal ions. The activation thermodynamic parameters, such as $\Delta \mathrm{E}^{*}, \Delta \mathrm{H}^{*}, \Delta \mathrm{S}^{*}, \Delta \mathrm{G}^{*}$ and $\mathrm{K}$ are calculated from the TGA curves using CoatsRedfern method. Hyper Chem-8 program has been used to predict structural geometries of compounds in the gas phase. The synthesized ligands and their metal complexes were screened for their biological activity against bacterial species, two Gram positive bacteria (Bacillus subtillis and Staphylococcus aureus) and two Gram negative bacteria (Escherichia coli and Pseudomonas aereuguinosa).
\end{abstract}

Keywords: Azo- Schiff base ligand, Kinetics, Thermodynamic parameters, Antibacterial activity, Spectroscopic investigation

\section{INTRODUCTION}

Schiff base derivatives attract significant interest and occupy an important role in the development of coordination chemistry. Moreover, Schiff base complexes containing transition metals have been studied in several research areas such as structural chemistry ${ }^{1}$. Azo compounds with two phenyl rings separated by an azo bond are very important in fundamental research area and applications ${ }^{2}$. In addition, azo-Schiff base derivatives are known to be important in several classes of medicinal and pharmaceutical fields. Furthermore, some of them show biological activities such as antibacterial, antifungal, anticancer and herbicidal activities ${ }^{3-12}$. However, the light induced interconversion allows systems incorporating azo group to be used as reversible control over a variety of chemical, electronic and mechanical applications ${ }^{2,13,14}$. Azo compounds metal complexes have also been attracting much attention because of their applications in dyes, pigment, functional materials and optical computing ${ }^{15}$. As part of our research in the study of coordinating capabilities of Azo-schiff base derivatives and their coordination compounds ${ }^{16}$, we report herein the synthesis and spectroscopic studies as well as the thermal investigation of a novel Azo-schiff base derivative Ligand (LH) ( $\mathrm{L}=2$ 2-[1,5-Dimethyl-3-[2-(5methyl-1H-indol-3-yl)-ethyl imino]-2-phenyl-2,3-dihydro-1H-pyrazol-4ylazo]-5-hydroxy-benzoic acid with some transition metals such as $\mathrm{Ni}^{\mathrm{II}}$, $\mathrm{Co}^{\mathrm{II}}$, $\mathrm{Cu}^{\mathrm{II}}, \mathrm{Pd}^{\mathrm{II}}$ and $\mathrm{Pt}^{\mathrm{II}}$ complexes. $\left({ }^{1} \mathrm{H},{ }^{13} \mathrm{C}\right) \mathrm{NMR}$ spectra were obtained to determine the structure of the ligand.

\section{EXPERIMENTAL}

2.1. Materials and measurements

All reagents were commercially available and used without further purification. Solvents were distilled from appropriate drying agents immediately prior to use.

Elemental analyses $(\mathrm{C}, \mathrm{H}$ and $\mathrm{N})$ were carried out on a Heraeus instrument (Vario EL). Melting points were obtained on a Buchi SMP-20 capillary melting point apparatus. IR spectra were recorded as $\mathrm{KBr}$ discs using a Shimadzu 8300 FTIR spectrophotometer in the range $(4000-400) \mathrm{cm}^{-1}$. Electronic spectra were measured in the region (200-1100) nm using $10^{-3} \mathrm{M}$ solutions in DMF at $25^{\circ} \mathrm{C}$ with a Shimadzu 160 spectrophotometer. NMR spectra $\left({ }^{1} \mathrm{H}-,{ }^{13} \mathrm{C}-\mathrm{NMR}\right)$ were recorded in DMSO- $d$, solution using Brucker AMX400 MHz spectrometer with tetramethylsilane (TMS) as an internal standard for ${ }^{1} \mathrm{H}$ NMR analysis. Metals were determined using a Shimadzu (A.A) $680 \mathrm{G}$ atomic absorption spectrophotometer. Chloride was determined using a potentiometric titration method on a 686-Titro processor-665Dosimat-Metrohm Swiss. Conductivity measurements were made with DMF solutions using a Jenway 4071 digital conductivity meter at room temperature. Electron impact mass spectra ( 70 eV) were recorded on a Finnegan-MAT model 8430 GC MS-DS spectrometer.
Magnetic moments were obtained using a magnetic susceptibility balance (Johnson Mattey Catalytic System Division). Thermal analysis studies of the ligand and complexes were performed on a Perkin-Elmer Pyris Diamond DTA/ TG Thermal System under nitrogen atmosphere with a heating rate of $10^{\circ} \mathrm{C} /$ min from $30-700^{\circ} \mathrm{C}$.

2.2. Synthesis of the compound 1,5-dimethyl-3-[2-(5-methyl-1H-indol-3yl)-ethylimino]-2-phenyl-2,3-dihydro-1H-pyrazol-4-ylamine (A)

An ethanolic solution $(15 \mathrm{ml})$ of 5-methyltryptamine hydrochloride ( $1.036 \mathrm{~g}, 0.00492 \mathrm{~mol}$ ) was added to a mixture containing an ethanolic solution $(25 \mathrm{ml})$ of 4-amino-1,5-dimethyl-2-phanyl-3-pyrazol-5-one (1 g, 0.00492 $\mathrm{mol})$. The reaction mixture was heated in a water bath at $40-50^{\circ} \mathrm{C}$ for $14 \mathrm{~h}$, in presence of $\mathrm{K}_{2} \mathrm{CO}_{3}$ after the addition of excess of ethanol $(50 \mathrm{ml})$. The resulting mixture was refluxed under $\mathrm{N}_{2}$. A white solid was formed, and then recrystallized from a water: ethanol (1:1) solvent mixture. The product was dried over anhydrous $\mathrm{CaCl}_{2}$ under vacuum. Yield: $53.76 \%(0.95 \mathrm{~g})$; MP: 177 ${ }^{\circ} \mathrm{C}$; ${ }^{1} \mathrm{H}$ NMR (DMSO- $\left.d_{6}, \mathrm{ppm}\right): \delta 1.89\left(\mathrm{~s},=\mathrm{CCH}_{3}\right), 2.10\left(\mathrm{~s}, \operatorname{arom}-\mathrm{CH}_{3}\right), 3.43$ $\left(\mathrm{s}, \mathrm{NCH}_{3}\right), 3.30\left(\mathrm{t}, \mathrm{NCH}_{2}\right), 2.74\left(\mathrm{t}, \mathrm{CCH}_{2}\right), 7.64-8.08(\mathrm{~m}, \operatorname{arom}), 12.11(\mathrm{~s}, \mathrm{NH})$, $4.10\left(\mathrm{~s}, \mathrm{NH}_{2}\right) .{ }^{13} \mathrm{C}-\mathrm{NMR}\left(100.622 \mathrm{MHz}\right.$, DMSO- $\left.d_{6}\right): \delta 16.39\left(\mathrm{C}_{20}\right), 18.87\left(\mathrm{C}_{3}\right)$, $38.79\left(\mathrm{C}_{13}\right), 45.6\left(\mathrm{C}_{12}\right), 58\left(\mathrm{C}_{1}\right), 98\left(\mathrm{C}_{17}\right), 100\left(\mathrm{C}_{711.14}\right), 110\left(\mathrm{C}_{18}\right), 111\left(\mathrm{C}_{1521}\right)$, $118\left(\mathrm{C}_{4}\right), 123.77\left(\mathrm{C}_{9}\right), 127\left(\mathrm{C}_{22}\right), 129\left(\mathrm{C}_{19}\right), 130\left(\mathrm{C}_{8,10}\right), 140\left(\mathrm{C}_{6}\right), 146\left(\mathrm{C}_{2}\right), 151\left(\mathrm{C}_{5}\right)$; $\mathrm{MS}, \mathrm{m} / \mathrm{z} 360,164,201$.

2.3. Synthesis of the ligand (LH) 2-[1,5-Dimethyl-3-[2-(5-methyl1H-indol-3-yl)-ethyl imino]-2-phenyl-2,3-dihydro-1H-pyrazol-4-ylazo]-5hydroxy-benzoic acid

A solution of $\mathrm{H}_{2} \mathrm{SO}_{4}(18 \mathrm{M}, 2 \mathrm{~mL})$, ethanol $(10 \mathrm{~mL})$ and distilled water $(10$ $\mathrm{ml})$, was used to dissolve $(0.5 \mathrm{~g}$, of (A) $(1.39 \mathrm{mmol})$. An aqueous solution (2 $\mathrm{mL})$ of $\mathrm{NaNO}_{2}(0.0144 \mathrm{~g}, 1 \mathrm{mmol})$ was added dropwise, while the temperature of the mixture was maintained between 0 and $5^{\circ} \mathrm{C}$. After that, the diazonium chloride was added with constant stirring to a cold ethanolic solution of $m$-hydroxybenzoic acid $(0.192 \mathrm{~g}, 1.39 \mathrm{~mol})$, and then a solution of $1 \mathrm{M} \mathrm{NaOH}$ $(25 \mathrm{ml})$ was added to the dark colored mixture. The mixture was stirred for $1 \mathrm{~h}$ at $0{ }^{\circ} \mathrm{C}$ and acidified with $1 \mathrm{~mL}$ of conc. $\mathrm{HCl}$. The brown product formed was filtered off and recrystallized from an ethanol-water $(1: 1)$ solution and then dried. Yield: $62.2 \%(0.44 \mathrm{~g}), \mathrm{mp} 390^{\circ} \mathrm{C}$ as shown in Scheme 1.

${ }^{1} \mathrm{H}$ NMR (DMSO- $\left.d, \quad \mathrm{ppm}\right): 1.89 \quad\left(\mathrm{~s}, \mathrm{C}-\mathrm{CH}_{3}\right), 2.10$ (s,arom- $\left.\mathrm{CH}_{3}\right)$, $3.43\left(\mathrm{~s}, \mathrm{NCH}_{3}\right), 3.30\left(\mathrm{t}, \mathrm{NCH}_{2}\right), 2.74\left(\mathrm{t}, \mathrm{CCH}_{2}\right), 4.49(\mathrm{~s}, \mathrm{O}-\mathrm{H}$ phenol), $7\left(\mathrm{~d}, \mathrm{C}_{25}-\mathrm{H}\right), 7.23\left(\mathrm{~s}, \mathrm{C}_{15}-\mathrm{H}\right), 7.36\left(\mathrm{~m}, \mathrm{C}_{711}-\mathrm{H}\right), 7.44\left(\mathrm{~m}, \mathrm{C}_{918.21}-\mathrm{H}\right), 7.85\left(\mathrm{~d}, \mathrm{C}_{24}-\mathrm{H}\right)$, $7.90\left(\mathrm{~m}, \mathrm{C}_{8,10} \mathrm{H}\right), 8.08\left(\mathrm{~d}, \mathrm{C}_{17} \mathrm{H}\right), 12.11(\mathrm{~d}, \mathrm{~N}-\mathrm{H}), 13$ (s, O-H carboxylic) ${ }^{13} \mathrm{C}_{24} \mathrm{NMR}$ $\left(100.6222_{8,10} \mathrm{MHz}\right.$, DMSO-d 6$) \delta 16.39\left(\mathrm{C}_{20}\right), 18.87\left(\mathrm{C}_{3}\right), 38.79\left(\mathrm{C}_{13}\right), 45.6\left(\mathrm{C}_{12}\right)$, $58\left(\mathrm{C}_{1}\right), 98\left(\mathrm{C}_{17}\right), 100\left(\mathrm{C}_{7111}\right), 106\left(\mathrm{C}_{25}\right), 110\left(\mathrm{C}_{18}\right), 111\left(\mathrm{C}_{23}\right), 111\left(\mathrm{C}_{1521}\right), 118\left(\mathrm{C}_{4}\right)$, $123.77\left(\mathrm{C}_{9}\right), 127\left(\mathrm{C}_{24}\right), 128\left(\mathrm{C}_{26}\right), 129\left(\mathrm{C}_{19}\right), 130\left(\mathrm{C}_{8,10}\right), 140\left(\mathrm{C}_{6}\right), 144\left(\mathrm{C}_{27}\right), 146\left(\mathrm{C}_{22}\right)$, $146\left(\mathrm{C}_{2}\right), 151\left(\mathrm{C}_{5}\right), 152\left(\mathrm{C}_{29}\right), 182\left(\mathrm{C}_{28}\right),(\mathrm{MS}) \mathrm{m} / \mathrm{z} 508\left(\mathrm{C}_{29} \mathrm{H}_{28} \mathrm{~N}_{6} \mathrm{O}_{3}\right), 345$ $\left(\mathrm{C}_{18} \mathrm{H}_{15} \mathrm{~N}_{5} \mathrm{O}_{3}\right)^{2-}, 159\left(\mathrm{C}_{11} \mathrm{H}_{13} \mathrm{~N}\right)$. 


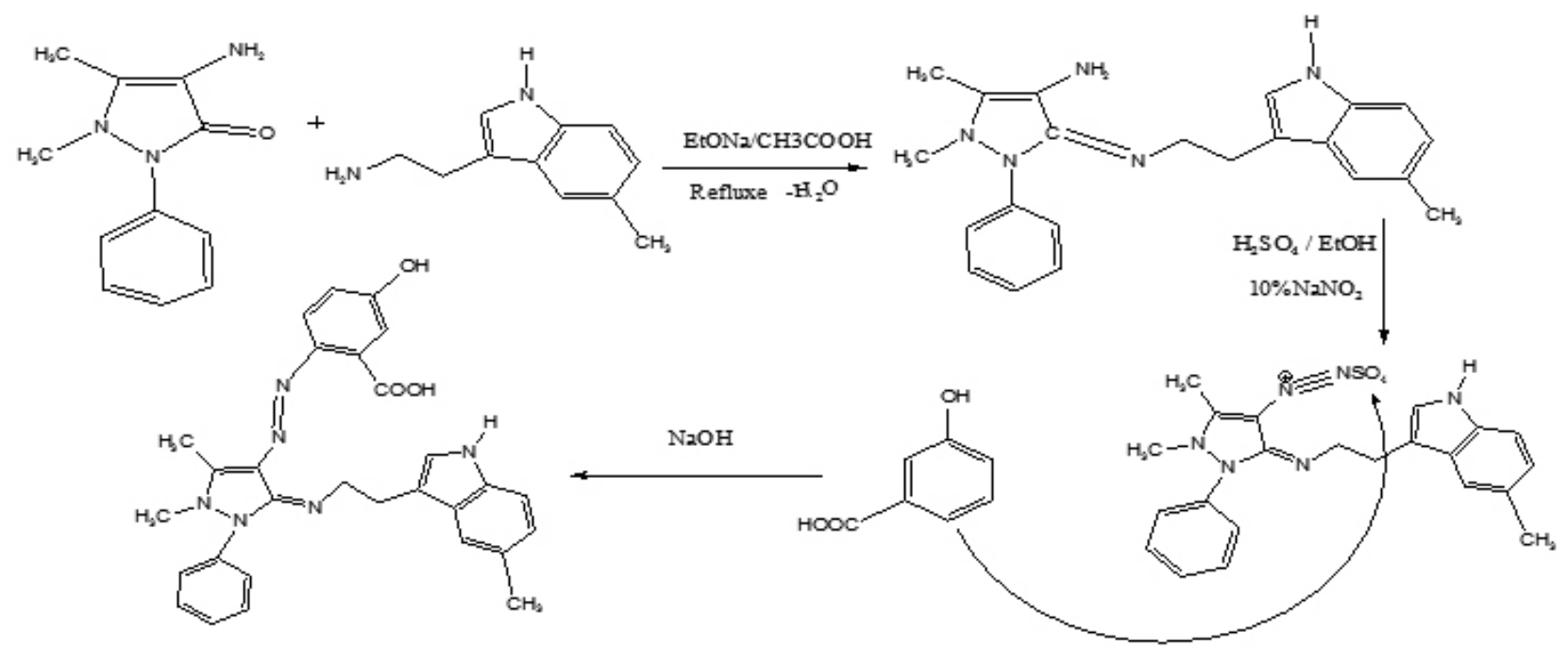
$(\mathrm{LH})$

Scheme1. Synthesis of 2-[1, 5-dimethyl-3-[2-(5-methyl-1H-indol-3-yl)-ethyl imino]-2-phenyl-2,3-dihydro-1H-pyrazol-4-ylazo]-5-hydroxy-benzoic acid

2.4. Syntheses of metal complexes

$\mathrm{Ni}^{\mathrm{II}}, \mathrm{Co}^{\mathrm{II}}, \mathrm{Cu}^{\mathrm{II}}, \mathrm{Pd}^{\mathrm{II}}$ and $\mathrm{Pt}^{\mathrm{II}}$ complexes were prepared by adding $10 \mathrm{~mL}$ of an ethanolic metal salt $(4 \mathrm{mmol})$ to an ethanol/chloroform $(1: 1 \mathrm{v} / \mathrm{v})$ solution containing $8 \mathrm{mmol}$ of the ligand (LH) and the mixture was refluxed for $6 \mathrm{~h}$. The obtained solution was left at room temperature and the resulting precipitates were filtered off, washed with ethanol and then recrystallized from an ethanol/ chloroform $(1: 3 \mathrm{v} / \mathrm{v})$ solvent mixture.

2.5. Microbiological investigations

The filter paper disc method was applied according to Gupta et al. ${ }^{17}$. The test bacteria were seeded in tubes with nutrient broth (NB). The seeded NB (1 $\mathrm{mL}$ ) was homogenized at $45^{\circ} \mathrm{C}$ in the tubes with $9 \mathrm{~mL}$ of melted nutrient agar (NA) and the homogeneous suspensions were poured into Petri dishes. The discs of filter paper (diameter $4 \mathrm{~mm}$ ) were ranged on the cooled medium. After cooling the formed solid medium of the investigated compounds were applied using a micropipette. After incubation for $24 \mathrm{~h}$ in a thermostat at $25-27^{\circ} \mathrm{C}$, the inhibition (sterile) zone diameters of the discs were measured and expressed in $\mathrm{mm}$. An inhibition zone diameter over $7 \mathrm{~mm}$ indicates that the tested compound is active against the bacteria under investigation. The antibacterial activities of the investigated compounds were tested against Escherichia coli and Pseudomonas aeruginosa as Gram negative, Bacillus subtilis and Staphylococcus aureus as Gram positive. The concentration of each solution was $10^{-3} \mathrm{M}$, commercial DMSO was employed to dissolve the tested samples. 2.6. Programs used in theoretical calculation

Hyper Chem-8 program is a sophisticated molecular modeler, editor and powerful computational package that are known for its quality, flexibility and ease of use, uniting 2D visualization and animation with quantum chemical calculations, molecular mechanics and dynamic. PM3 is more popular than other semi-empirical methods due to the availability of algorithms and more accurate than with other methods. PM3/TM is an extension of the PM3 method to include orbital's for use with transition metals. It has parameterized primarily for organic molecules and selected transition metals. In the present work, parameterization method 3 (PM3) was used for the calculation of heat of formation and binding energy for all metal complexes.

\section{RESULTS AND DISCUSSION}

All the prepared complexes in this paper were insoluble in water but soluble in dimethyl formamide. The range of conductance values in DMF which are listed in table 1 indicates that all the metal complexes have a nonelectrolyte nature. Thus, the molar conductance value indicate that the $\mathrm{Cl}$ anion is in the first coordination sphere of the metal ${ }^{15,17,18}$. The physical properties and elemental analysis data are listed in Table 1.

Table 1. Physical properties, conductivity and analytical data of the free ligands and its complexes

\begin{tabular}{|c|c|c|c|c|c|c|c|c|c|}
\hline \multirow{2}{*}{$\begin{array}{l}\text { Compound } \\
\text { Formula }\end{array}$} & \multirow{2}{*}{$\begin{array}{c}\text { Yield } \\
\%\end{array}$} & \multirow{2}{*}{ Color } & \multirow{2}{*}{$\begin{array}{l}\text { M.P. } \\
{ }^{\circ} \mathrm{C}\end{array}$} & \multicolumn{5}{|c|}{ Elemental Analysis Calculated (Found) \% } & \multirow{2}{*}{$\begin{array}{l}\text { Molar conductivity } \\
\mathrm{Ohm}^{-1} \mathrm{~cm}^{2} \mathrm{~mol}^{-1}\end{array}$} \\
\hline & & & & $\mathrm{C}$ & $\mathrm{H}$ & $\mathrm{N}$ & M & $\mathrm{Cl}$ & \\
\hline $\begin{array}{c}\mathrm{A} \\
\mathrm{C}_{22} \mathrm{H}_{25} \mathrm{~N}_{5}\end{array}$ & 62.2 & White & 177 & $\begin{array}{l}73.51 \\
(75.55\end{array}$ & $\begin{array}{c}7.01 \\
(6.87)\end{array}$ & $\begin{array}{c}19.48 \\
(21.23)\end{array}$ & - & - & - \\
\hline $\begin{array}{c}\mathrm{L} \\
\mathrm{C}_{29} \mathrm{H}_{28} \mathrm{~N}_{6} \mathrm{O}_{3}\end{array}$ & 62.2 & $\begin{array}{l}\text { Brown } \\
\text { Yellow }\end{array}$ & $>390$ & $\begin{array}{l}(68.4) \\
67.76\end{array}$ & $\begin{array}{c}(5.55) \\
5.83\end{array}$ & $\begin{array}{c}(16.52) \\
16.56\end{array}$ & - & - & - \\
\hline $\begin{array}{c}{\left[\mathrm{CoL}\left(\mathrm{H}_{2} \mathrm{O}\right)_{2} \mathrm{Cl}\right]} \\
\mathrm{C}_{29} \mathrm{H}_{31} \mathrm{~N}_{6} \mathrm{O}_{5} \mathrm{ClCo}\end{array}$ & 66 & $\begin{array}{l}\text { Brown } \\
\text { reddish }\end{array}$ & $220 \mathrm{~d}$ & $\begin{array}{c}(54.60) \\
54.83\end{array}$ & $\begin{array}{c}(4.90) \\
3.99\end{array}$ & $\begin{array}{c}(13.17) \\
14.31\end{array}$ & $\begin{array}{l}(9.24) \\
10.12\end{array}$ & $\begin{array}{c}(5.56) \\
4.78\end{array}$ & 15 \\
\hline $\begin{array}{c}{\left[\mathrm{NiL}\left(\mathrm{H}_{2} \mathrm{O}\right)_{2} \mathrm{Cl}\right]} \\
\mathrm{C}_{29} \mathrm{H}_{31} \mathrm{~N}_{6} \mathrm{O}_{5} \mathrm{ClNi}\end{array}$ & 68 & $\begin{array}{l}\text { Yellow- } \\
\text { green }\end{array}$ & $235 \mathrm{~d}$ & $\begin{array}{c}(54.62) \\
55.07\end{array}$ & $\begin{array}{c}(4.90) \\
4.47\end{array}$ & $\begin{array}{c}(13.18) \\
13.01\end{array}$ & $\begin{array}{c}(9.20) \\
8.53\end{array}$ & $\begin{array}{c}(5.56) \\
4.27\end{array}$ & 25 \\
\hline $\begin{array}{c}{\left[\mathrm{CuL}\left(\mathrm{H}_{2} \mathrm{O}\right)_{2} \mathrm{Cl}\right]} \\
\mathrm{C}_{29} \mathrm{H}_{31} \mathrm{~N}_{6} \mathrm{O}_{5} \mathrm{ClCu}\end{array}$ & 71 & Dark red & $300 \mathrm{~d}$ & $\begin{array}{c}(54.20) \\
55.07\end{array}$ & $\begin{array}{c}(4.86) \\
5.55\end{array}$ & $\begin{array}{c}(13.08) \\
14.01\end{array}$ & $\begin{array}{c}(9.89) \\
8.79\end{array}$ & $\begin{array}{c}(5.52) \\
4.79\end{array}$ & 18 \\
\hline $\begin{array}{c}{[\mathrm{PdLCl}]} \\
\mathrm{C}_{29} \mathrm{H}_{27} \mathrm{~N}_{6} \mathrm{O}_{3} \mathrm{ClPd}\end{array}$ & 55 & $\begin{array}{l}\text { Brown } \\
\text { reddish }\end{array}$ & $280 \mathrm{~d}$ & $\begin{array}{c}(53.63) \\
54.05\end{array}$ & $\begin{array}{c}(4.19) \\
3.85\end{array}$ & $\begin{array}{c}(12.94) \\
13.52\end{array}$ & $\begin{array}{c}(16.39) \\
15.76\end{array}$ & $\begin{array}{c}(5.46) \\
4.87\end{array}$ & 23 \\
\hline $\begin{array}{c}{\left[\mathrm{PtLCl}_{3}\right]} \\
\mathrm{C}_{29} \mathrm{H}_{27} \mathrm{~N}_{6} \mathrm{O}_{3} \mathrm{Cl}_{3} \mathrm{Pt}\end{array}$ & 59 & Brown & $280 \mathrm{~d}$ & $\begin{array}{c}(43.05) \\
44.22\end{array}$ & $\begin{array}{c}(3.36) \\
3.88\end{array}$ & $\begin{array}{c}(10.39) \\
11.05\end{array}$ & $\begin{array}{c}(24.11) \\
23.97\end{array}$ & $\begin{array}{c}(13.15) \\
12.12\end{array}$ & 30 \\
\hline
\end{tabular}

$\mathrm{d}=$ decomposes 
3.1. Electronic spectra and magnetic moments

The electronic spectrum of the free ligand (LH) shows two bands at 275 $\mathrm{nm}$ and $300 \mathrm{~nm}$ which are attributed to $\pi 囚 \pi^{*}$ and $n \circledR \pi^{*}$ transitions respectively. The electronic spectrum of the $\mathrm{Co}^{\Pi}$ complex exhibits three absorption band at 400,500 and $648 \mathrm{~nm}$ which were attributed to ${ }^{4} \mathrm{~T}_{1} \mathrm{~g}_{(\mathrm{F})}{ }^{\circledR}{ }^{4} \mathrm{~A}_{2} \mathrm{~g}_{(\mathrm{F})},{ }^{4} \mathrm{~T}_{1} \mathrm{~g}_{(\mathrm{F})}{ }^{\circledR}{ }^{4} \mathrm{~T}_{1} \mathrm{~g}_{(\mathrm{P}}$ and ${ }^{4} \mathrm{~T}_{1} \mathrm{~g}_{(\mathrm{F})}{ }^{\circledR}{ }^{4} \mathrm{~T}_{2} \mathrm{~g}_{(\mathrm{F})}$ respectively. Furthermore, the magnetic moment of the $\mathrm{Co}^{\mathrm{Il}}$ $\left(d^{7}\right)$ complex was found to be 5.01 B.M., which is higher than the spin only calculated value, difference that can be attributed to the orbital contribution. All the above mentioned data correspond to an octahedral geometry ${ }^{19-22}$.

The electronic spectrum of the yellow-green $\mathrm{Ni}^{\mathrm{II}}$ complex shows bands in the visible region at 394, 490 and $650 \mathrm{~nm}$, which are assigned to the d-d electronic transitions ${ }^{3} \mathrm{~A}_{2 \mathrm{~g}(\mathrm{~F})}{ }^{\circledR}{ }^{3} \mathrm{~T}_{1 \mathrm{~g}(\mathrm{P})},{ }^{3} \mathrm{~A}_{2} \mathrm{~g}_{(\mathrm{F})}{ }^{\circledR}{ }^{3} \mathrm{~T}_{2} \mathrm{~g}_{(\mathrm{F})}$ and ${ }^{3} \mathrm{~A}_{2} \mathrm{~g}_{(\mathrm{F})}{ }^{\circledR}{ }^{3} \mathrm{~T}_{1} \mathrm{~g}_{(\mathrm{F})}$ respectively. The value of $\mu_{\text {eff }}$ of the $\mathrm{Ni}^{\mathrm{II}}$ complex $d^{8}$ is $2.82 \mathrm{~B} . \mathrm{M}$; this value is in agreement with the spin-only value. All these results for the $\mathrm{Ni}^{\mathrm{II}}$ complex confirm an octahedral geometry ${ }^{20}$
The copper complex exhibits absorption bands at 289 and $385 \mathrm{~nm}$ which

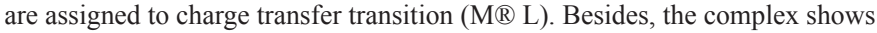
a band in the visible region at $590 \mathrm{~nm}$ which can be assigned to $2 \mathrm{Eg}\left({ }^{2} \mathrm{~T}_{2} \mathrm{~g}_{(\mathrm{D})}\right.$. The $\mu_{\text {eff }}$ of the $\mathrm{Cu}^{\mathrm{II}}$ complex $d^{9}$ was found to be $1.82 \mathrm{~B}$. M within the expected value for one electron ${ }^{23}$.

The diamagnetic $\mathrm{Pd}^{\mathrm{II}} d^{8}$ low spin complex exhibits absorption bands at 410 and $492 \mathrm{~nm}$ which assigned to ${ }^{1} \mathrm{~A}_{1} \mathrm{~g}{ }^{\circledR}{ }^{1} \mathrm{~A}_{2} \mathrm{~g}$ and another band at $790 \mathrm{~nm}$ which can be assigned to ${ }^{1} \mathrm{~A}_{1} \mathrm{~g}{ }^{\circledR}{ }^{1} \mathrm{~B}_{1} \mathrm{~g}$. These assignments correspond to a square planar $\mathrm{Pd}^{\mathrm{II}}$ complex ${ }^{20,24}$.

Finally, the spectrum of brown $\mathrm{Pt}^{\mathrm{II}}$ complex show electronic transitions of ${ }^{1} \mathrm{~A}_{1} \mathrm{~g}{ }^{\circledR}{ }^{1} \mathrm{~T}_{2} \mathrm{~g}$ and ${ }^{1} \mathrm{~A}_{1} \mathrm{~g}{ }^{\circledR}{ }^{1} \mathrm{~T}_{1} \mathrm{~g}$ at 495 and $792 \mathrm{~nm}$ respectively. Table 2 gives the electronic spectral bands and the magnetic moments of the ligand and its complexes.

Table 2. Magnetic susceptibility and electronic specta of the ligand and the reported complexes

\begin{tabular}{|c|c|c|c|c|c|}
\hline Compound & $\begin{array}{c}\lambda_{\max } \\
\mathrm{nm}\end{array}$ & $\begin{array}{l}\text { Wave number } \\
\mathrm{cm}^{-1}\end{array}$ & $\mathrm{~L} \mathrm{~mol}_{\mathrm{max}^{-1} \mathrm{~cm}^{-1}}$ & Assignment & $\begin{array}{l}\mu_{\text {eff }} \text { Calc. } \\
\text { (found) B.M }\end{array}$ \\
\hline \multirow{2}{*}{ A } & 280 & 35714 & 35000 & $\pi \rightarrow \pi^{*}$ & \multirow{2}{*}{-} \\
\hline & 300 & 33333 & 36900 & $\mathrm{n} \rightarrow \pi^{*}$ & \\
\hline \multirow{2}{*}{$\mathrm{LH}$} & 275 & 36363 & 30000 & $\pi \rightarrow \pi^{*}$ & \multirow{2}{*}{ - } \\
\hline & 300 & 33333 & 34500 & $\mathrm{n} \rightarrow \pi^{*}$ & \\
\hline \multirow{4}{*}[\mathrm{CoL}(\mathrm{H}_{2}\mathrm{O})_{2}\mathrm{Cl}]{} & 346 & 28901 & 520 & $\mathrm{M} \rightarrow \mathrm{L}(\mathrm{C} . \mathrm{T})$ & \multirow{4}{*}{$\begin{array}{l}3.872 \\
(5.01)\end{array}$} \\
\hline & 400 & 25000 & 650 & ${ }^{4} \mathrm{~T}_{1} \mathrm{~g}_{(\mathrm{F})} \rightarrow{ }^{4} \mathrm{~A}_{2} \mathrm{~g}_{(\mathrm{F})}$ & \\
\hline & 500 & 20000 & 190 & ${ }^{4} \mathrm{~T}_{1} \mathrm{~g}_{(\mathrm{F})} \rightarrow{ }^{4} \mathrm{~T}_{1} \mathrm{~g}_{(\mathrm{P})}$ & \\
\hline & 648 & 15432 & 185 & ${ }^{4} \mathrm{~T}_{1} \mathrm{~g}_{(\mathrm{F})} \rightarrow{ }^{4} \mathrm{~T}_{2} \mathrm{~g}_{(\mathrm{F})}$ & \\
\hline \multirow{4}{*}[\mathrm{NiL}(\mathrm{H}_{2}\mathrm{O})_{2}\mathrm{Cl}]{} & 340 & 29411 & 110 & $\mathrm{M} \otimes L(C . T)$ & \multirow{4}{*}{$\begin{array}{l}2.828 \\
(2.82)\end{array}$} \\
\hline & 394 & 25380 & 120 & ${ }^{3} \mathrm{~A}_{2} \mathrm{~g}_{(\mathrm{F})} \rightarrow{ }^{3} \mathrm{~T}_{1} \mathrm{~g}_{(\mathrm{P})}$ & \\
\hline & 490 & 20408 & 36 & ${ }^{3} \mathrm{~A}_{2} \mathrm{~g}_{(\mathrm{F})} \rightarrow{ }^{3} \mathrm{~T}_{2} \mathrm{~g}_{(\mathrm{F})}$ & \\
\hline & 650 & 15384 & 40 & ${ }^{3} \mathrm{~A}_{2} \mathrm{~g}_{(\mathrm{F})} \rightarrow{ }^{3} \mathrm{~T}_{1} \mathrm{~g}_{(\mathrm{F})}$ & \\
\hline \multirow{3}{*}[\mathrm{CuL}(\mathrm{H}_{2}\mathrm{O})_{2}\mathrm{Cl}]{} & 289 & 34602 & 140 & $\mathrm{M} \rightarrow \mathrm{L}(\mathrm{C} . \mathrm{T})$ & \multirow{3}{*}{$\begin{array}{l}1.732 \\
(1.82)\end{array}$} \\
\hline & 385 & 25974 & 140 & $\mathrm{n} \rightarrow \pi^{*}$ & \\
\hline & 590 & 16949 & 24 & ${ }^{2} \mathrm{Eg}_{(\mathrm{D}) \rightarrow}{ }^{2} \mathrm{~T}_{2} \mathrm{~g}_{(\mathrm{D})}$ & \\
\hline \multirow{4}{*}[\mathrm{PdLCl}]{} & 380 & 26315 & 2150 & $\mathrm{M} \rightarrow \mathrm{L}(\mathrm{C} . \mathrm{T})$ & \multirow{4}{*}{ Diamagnetic } \\
\hline & 410 & 24390 & 3200 & \multirow{2}{*}{${ }^{1} \mathrm{~A}_{1} \mathrm{~g} \rightarrow{ }^{1} \mathrm{~A}_{2} \mathrm{~g}$} & \\
\hline & 492 & 20325 & 390 & & \\
\hline & 790 & 12658 & 400 & ${ }^{1} \mathrm{~A}_{1} \mathrm{~g} \rightarrow{ }^{1} \mathrm{~B}_{1} \mathrm{~g}$ & \\
\hline \multirow{3}{*}[\mathrm{PtLCl}_{3}]{} & 289 & 34602 & 780 & $\pi \rightarrow \pi^{*}$ & \multirow{3}{*}{$(0.90)$} \\
\hline & 495 & 20202 & 160 & ${ }^{1} \mathrm{~A}_{1} \mathrm{~g} \rightarrow{ }^{1} \mathrm{~T}_{2} \mathrm{~g}$ & \\
\hline & 792 & 12626 & 120 & ${ }^{1} \mathrm{~A}_{1} \mathrm{~g} \rightarrow{ }^{1} \mathrm{~T}_{1} \mathrm{~g}$ & \\
\hline
\end{tabular}

\subsection{Infrared spectra studies}

The main vibrational bands of the FTIR spectrum were assigned to the functional groups of the Azo-Schiff base ligand LH. The spectrum of the ligand shows strong bands at 3699, 3429, 3234, 1728, 1601, 1444, 1342 and 1288 $\mathrm{cm}^{-1}$ that are assigned to the $v(\mathrm{OH})$ carboxyl, $v(\mathrm{OH})$ phenolic, $v(\mathrm{NH}), v(\mathrm{C}=\mathrm{N})$ $v(\mathrm{COO})$ asymmetrical, $v(\mathrm{~N}=\mathrm{N}), v(\mathrm{COO})$ symmetrical and $v(\mathrm{CO})$ phenolic respectively ${ }^{25-27}$. On complex formation the bands of $v(\mathrm{C}=\mathrm{N}), v(\mathrm{~N}=\mathrm{N})$ and $v(\mathrm{COO})$ are shifted to lower frequencies by (39 to 44$),(8$ to 18 ) and ( 3 to 8 ) $\mathrm{cm}^{-1}$ respectively; these shifts confirm the coordination of the ligand through the nitrogen of the azomethine group, and the azo group and the carboxylate ion with the metal ions. Moreover, the spectra of the complexes exhibited weak bands between $(534-553) \mathrm{cm}^{-1}$ and $(437-454) \mathrm{cm}^{-1}$ which are attributed to $v(\mathrm{M}-\mathrm{N})$ and $v(\mathrm{M}-\mathrm{O})$ respectively. This indicates that the ligand is coordinated to the metal ions through the $\mathrm{N}$ and $\mathrm{O}$ atoms. Besides, the spectra of the complexes present weak bands between $407-412 \mathrm{~cm}^{-1}$ which can be assigned to $v(\mathrm{M}-\mathrm{Cl})^{28}$. Characteristic vibrations and assignments of free the ligand and its complexes are reported in Table 3 . 
Table 3. The IR spectra bands $\left(\mathrm{cm}^{-1}\right)$ of the free ligand and its complexes

\begin{tabular}{|c|c|c|c|c|c|c|c|c|c|}
\hline Compound & $v(\mathrm{OH})_{\text {ca }}$ & $\begin{array}{l}v(\mathrm{OH})_{\mathrm{Ph}} \\
v(\mathrm{CO})_{\mathrm{ph}}\end{array}$ & $v(\mathrm{NH})$ & $v(\mathrm{C}=\mathrm{N})$ & $v(\mathrm{~N}=\mathrm{N}), v(\mathrm{C}-\mathrm{N}=\mathrm{N}-\mathrm{C})$ & $\begin{array}{l}v(\mathrm{COO})_{\mathrm{as}} \\
\mathrm{v}(\mathrm{COO})_{\mathrm{s}}\end{array}$ & $\begin{array}{l}v(\mathrm{M}-\mathrm{N}) \\
v(\mathrm{M}-\mathrm{O})\end{array}$ & $v(\mathrm{M}-\mathrm{Cl})$ & $v\left(\mathrm{H}_{2} \mathrm{O}\right)$ \\
\hline $\mathrm{L}$ & 3699 & $\begin{array}{l}3492 \\
1288\end{array}$ & 3234 & 1728 & 1444,1124 & $\begin{array}{l}1601 \\
1342\end{array}$ & - & & - \\
\hline$\left[\mathrm{NiL}\left(\mathrm{H}_{2} \mathrm{O}\right)_{2} \mathrm{Cl}\right]$ & - & $\begin{array}{l}3429 \\
1280\end{array}$ & 3239 & 1687 & 1427,1120 & $\begin{array}{l}1598 \\
1333\end{array}$ & $\begin{array}{l}540 \\
440\end{array}$ & 407 & 3539 \\
\hline$[\mathrm{PdLCl}]$ & - & $\begin{array}{l}3425 \\
1289\end{array}$ & 3231 & 1685 & 1437,1124 & $\begin{array}{l}1584 \\
1336\end{array}$ & $\begin{array}{l}540 \\
454\end{array}$ & 410 & - \\
\hline$\left[\mathrm{PtLCl}_{3}\right]$ & - & $\begin{array}{l}3426 \\
1289\end{array}$ & 3239 & 1684 & 1434,1124 & $\begin{array}{l}1583 \\
1337\end{array}$ & $\begin{array}{l}553 \\
443\end{array}$ & 411 & - \\
\hline
\end{tabular}

$\mathrm{Ph}=$ phenolic, $\mathrm{ca}=$ carboxylic, as $=$ asymmetric, $\mathrm{s}=$ symmetric

\subsection{Thermal analysis $T G A$}

To understand the thermal decomposition processes of the studied compounds, the azo-Schiff base ligand and its metal complexes were examined by thermo gravimetric analysis in the temperature range of $30-700{ }^{\circ} \mathrm{C}$. The obtained results from the TG curves for all these compounds are given in Table 4. The decomposition was complete at $693{ }^{\circ} \mathrm{C}$ for all the complexes.. The comparison of the thermograms of the ligand and the complexes shows that the complexes are more thermally stable than the Azo-Schiff base $\left(10-35^{\circ} \mathrm{C}\right)$. The final decomposition products were metal Pd complex in $\left(600^{\circ} \mathrm{C}\right)$, metal oxide $\mathrm{CoO}$ in the $696{ }^{\circ} \mathrm{C}, \mathrm{NiO} 698{ }^{\circ} \mathrm{C}$ and $\mathrm{PtO} 598{ }^{\circ} \mathrm{C}$ ) and metal mixture formed above $600{ }^{\circ} \mathrm{C}$ for the $\mathrm{Cu}$ complex

The thermal data have been analyzed for thermodynamic parameters by using Coats- Redfern method. From the half decomposition temperature, the relative thermal stability of the compounds is: $\mathrm{NiL}>\mathrm{CoL}>\mathrm{PdL}>\mathrm{CuL}>\mathrm{PtL}>\mathrm{L}$

$(\mathrm{L})=\mathrm{C}_{29} \mathrm{H}_{28} \mathrm{~N}_{6} \mathrm{O}_{3} \quad\left[101.131 \%\right.$ Found $\quad(99.999 \% \quad \mathrm{Cal}) \quad\left(158-348^{\circ} \mathrm{C}\right)$ $\rightarrow \mathrm{C}_{23} \mathrm{H}_{3} \mathrm{~N}_{5} \mathrm{O}_{2} \quad[82.648 \%$ Found $\quad(82.085 \% \quad \mathrm{Cal})] \quad\left(348-598 \quad{ }^{\circ} \mathrm{C}\right) \quad \rightarrow$ $\mathrm{C}_{6} \mathrm{H}_{5} \mathrm{~N}-\left[18.483 \%\right.$ Found $(17.914 \% \mathrm{Cal}) ; \mathrm{C}_{29} \mathrm{H}_{31} \mathrm{~N}_{6} \mathrm{O}_{5} \mathrm{ClCu}(642.59)\left(35-142^{\circ} \mathrm{C}\right)$ $\rightarrow 2 \mathrm{H}_{2} \mathrm{O}[4.931 \%$ Found $(5.607 \% \mathrm{Cal})] ; \mathrm{C}_{29} \mathrm{H}_{27} \mathrm{~N}_{6} \mathrm{O}_{3} \mathrm{ClCu}(606.59)\left(142-435^{\circ} \mathrm{C}\right)$ $\rightarrow \mathrm{C}_{9}^{2} \mathrm{H}_{11} \mathrm{~N}[22.003 \%$ Found $(20.716 \% \mathrm{Cal})] ; \mathrm{C}_{20}{ }_{30}^{3} \mathrm{H}_{16} \mathrm{~N}_{5} \mathrm{O}_{3} \mathrm{ClCu}(473.59)(435-$ $\left.600^{\circ} \mathrm{C}\right) \rightarrow \mathrm{C}_{13} \mathrm{H}_{12} \mathrm{~N}_{3} \mathrm{Cl}\left[38.174 \%\right.$ found $(38.239 \% \mathrm{Cal}) ; \mathrm{C}_{7} \mathrm{H}_{4} \mathrm{CuN}_{2} \mathrm{O}_{3}[35.438 \%$ Found $(35.358 \% \mathrm{Cal})]$.

Total wt. $\operatorname{loos}=65.003 \%$ Found $(64.562 \% \mathrm{Cal})$ and final residue: $34.997 \%$ Found $(35.438 \% \mathrm{Cal})$
$\mathrm{C}_{29} \mathrm{H}_{27} \mathrm{~N}_{6} \mathrm{O}_{3} \mathrm{ClPd}$ (649.44) (35-412 $\left.{ }^{\circ} \mathrm{C}\right) \rightarrow \mathrm{C}_{18} \mathrm{H}_{17} \mathrm{~N}_{3} \quad$ [42.814\% Found (42.344 \% $\%$ Cal) $] ; \mathrm{C}_{11} \mathrm{H}_{10} \mathrm{~N}_{3} \mathrm{O}_{4} \mathrm{ClPd}(390.44)\left(412-600^{\circ} \mathrm{C}\right) \rightarrow \mathrm{C}_{11} \mathrm{H}_{10} \mathrm{~N}_{3} \mathrm{O}_{2} \mathrm{Cl}$ [44.124\% Found (41.19\% \%al)]; Pd [13.062\% Found $(16.387 \% \mathrm{Cal})]$

Total wt. loos $=86.938 \%$ Found $(83.534 \% \mathrm{Cal})$ and final residue: 13.062 $\%$ Found $(16.466 \% \mathrm{Cal})$

$\mathrm{C}_{29} \mathrm{H}_{31} \mathrm{~N}_{6} \mathrm{O}_{5} \mathrm{ClNi}(637.74)\left(45-170^{\circ} \mathrm{C}\right) \rightarrow 2 \mathrm{H}_{2} \mathrm{O}+\mathrm{CH}_{7} \mathrm{ClO}[16.823 \%$ Found $(16.707 \% \mathrm{Cal})] ; \quad \quad \mathrm{C}_{28} \mathrm{H}_{18} \mathrm{~N}_{6} \mathrm{O}_{2} \mathrm{Ni}(567.24)\left(170-355^{\circ} \mathrm{C}\right) \rightarrow \mathrm{C}_{7} \mathrm{H}_{10} \mathrm{~N}$ [20.175\% Found $(19.156 \% \mathrm{Cal})] ; \mathrm{C}_{21} \mathrm{H}_{8} \mathrm{~N}_{4} \mathrm{O}_{2}(348)\left(355-698^{\circ} \mathrm{C}\right) \rightarrow \mathrm{C}_{21} \mathrm{H}_{8} \mathrm{~N}_{4} \mathrm{O}$ [52.903\% Found $(54.004 \% \mathrm{Cal})$; $\mathrm{NiO}[10.099 \%$ Found $(11.712 \% \mathrm{Cal})]$

Total wt. loos $=89.901 \%$ Found $(89.867 \% \mathrm{Cal})$ and final residue: $10.099 \%$ Found $(10.133 \% \mathrm{Cal})$

$\mathrm{C}_{29} \mathrm{H}_{31} \mathrm{~N}_{6} \mathrm{O}_{5} \mathrm{ClCo} \quad(637.98) \quad\left(45-150^{\circ} \mathrm{C}\right) \rightarrow 2 \mathrm{H}_{2} \mathrm{O}+\mathrm{C} \quad[7.647 \%$ Found $(7.528 \% \mathrm{Cal})] ; \quad \mathrm{C}_{28} \mathrm{H}_{27} \mathrm{~N}_{6} \mathrm{O}_{3} \mathrm{CoCl} \quad(589.95) \quad\left(150-430^{\circ} \mathrm{C}\right) \rightarrow \mathrm{C}_{7} \mathrm{H}_{10} \mathrm{~N}_{2} \mathrm{ClO}_{2}$ [31.601\% Found $(29.725 \% \mathrm{Cal})] ; \mathrm{C}_{21} \mathrm{H}_{17} \mathrm{~N}_{4} \mathrm{O}(341)\left(430-696^{\circ} \mathrm{C}\right) \rightarrow \mathrm{C}_{21} \mathrm{H}_{17} \mathrm{~N}_{4}$ [52.310\% Found $(50.942 \% \mathrm{Cal})$; CoO [ $8.442 \%$ Found $(9.237 \% \mathrm{Cal})]$

Total wt. loos $=91.558 \%$ Found $(88.195 \% \mathrm{Cal})$ and final residue: $8.442 \%$ Found $(11.745 \% \mathrm{Cal})$

$1-\mathrm{C}_{20} \mathrm{H}_{27} \mathrm{~N}_{6} \mathrm{O}_{3} \mathrm{Cl}_{3} \mathrm{Pt} \quad(809) \quad\left(45-145^{\circ} \mathrm{C}\right) \quad \rightarrow \mathrm{C}_{3} \quad \mathrm{H} \quad[4.931 \% \quad$ Found $(50191 \% \mathrm{Cal})] ; \mathrm{C}_{26} \mathrm{H}_{21} \mathrm{~N}_{6} \mathrm{O}_{3} \mathrm{Cl}_{3} \mathrm{Pt}(767)\left(145-445^{\circ} \mathrm{C}\right) \rightarrow \mathrm{C}_{8} \mathrm{H}_{10} \mathrm{Cl}_{2} \quad[22.003 \%$ Found $(21867 \% \mathrm{Cal})] ; \mathrm{C}_{18} \mathrm{H}_{11} \mathrm{~N}_{6} \mathrm{O}_{3} \mathrm{Cl} \mathrm{Pt}(590.096)\left(445-598^{\circ} \mathrm{C}\right) \stackrel{\mathrm{C}_{22}}{\rightarrow} \mathrm{H}_{17} \mathrm{~N}_{5}$ [47.166\% Found $(47.213 \% \mathrm{Cal})]$; ptO [25.906\% Found $(25.729 \% \mathrm{Cal})]$; Total wt. loos $=74.094 \%$ Found $(74.271 \% \mathrm{Cal})$ and final residue: $25.906 \%$ Found $(25.729 \% \mathrm{Cal})$

Table 4. Thermal analysis data of the metal complexes derived from $\mathrm{L}$.

\begin{tabular}{|c|c|c|c|c|c|}
\hline \multirow{2}{*}{ Com } & \multirow{2}{*}{ TG range $\left({ }^{\circ} \mathrm{C}\right)$} & \multirow{2}{*}{$\mathrm{DTG}_{\text {max }}\left({ }^{\circ} \mathrm{C}\right)$} & \multicolumn{2}{|c|}{ \%Estimated (calculated) } & \multirow{2}{*}{ Assignment } \\
\hline & & & Mass Loss & Total mass Loss & \\
\hline $\mathrm{L}$ & $\begin{array}{l}158-348 \\
348-598\end{array}$ & $\begin{array}{l}290.36 \\
513.87\end{array}$ & $\begin{array}{l}82.648(82.085) \\
18.483(17.914)\end{array}$ & $\begin{array}{l}101.131 \\
(99.999)\end{array}$ & $\begin{array}{c}\mathrm{C}_{23} \mathrm{H}_{23} \mathrm{~N}_{5} \mathrm{O}_{3} \\
\mathrm{C}_{6} \mathrm{H}^{5} \mathrm{~N}-\end{array}$ \\
\hline$\left[\mathrm{CoL}\left(\mathrm{H}_{2} \mathrm{O}\right)_{2} \mathrm{Cl}\right]$ & $\begin{array}{c}45-150 \\
150430 \\
430-696 \\
\end{array}$ & $\begin{array}{c}72.03 \\
359.39 \\
476.91 \\
\end{array}$ & $\begin{array}{c}7.64(7.528) \\
31.601(29.725) \\
52.310(50.942) \\
8.442(9.237)\end{array}$ & $\begin{array}{c}91.558 \\
(88.195)\end{array}$ & $\begin{array}{c}2 \mathrm{H}_{2} \mathrm{O} \\
\mathrm{C}_{7} \mathrm{H}_{10} \mathrm{~N}_{2} \mathrm{ClO}_{2} \\
\mathrm{C}_{21} \mathrm{H}_{17} \mathrm{~N}_{4} \\
\mathrm{CoO}\end{array}$ \\
\hline$\left[\mathrm{NiL}\left(\mathrm{H}_{2} \mathrm{O}\right)_{2} \mathrm{Cl}\right]$ & $\begin{array}{c}45-170 \\
170-355 \\
355-698\end{array}$ & $\begin{array}{c}75.35 \\
263.96 \\
477.38\end{array}$ & $\begin{array}{l}16.823(16.707) \\
20.175(19.156) \\
52.903(54.004) \\
10.099(11.712) \\
\end{array}$ & $\begin{array}{c}89.901 \\
(89.867)\end{array}$ & $\begin{array}{c}2 \mathrm{H}_{2} \mathrm{O}+\mathrm{CH}_{7} \mathrm{ClO} \\
\mathrm{C}_{7} \mathrm{H}_{10} \mathrm{~N}_{2} \\
\mathrm{C}_{21} \mathrm{H}_{8} \mathrm{~N}_{4} \mathrm{O} \\
\mathrm{NiO} \\
\mathrm{ilO}\end{array}$ \\
\hline$\left[\mathrm{CuL}\left(\mathrm{H}_{2} \mathrm{O}\right)_{2} \mathrm{Cl}\right]$ & $\begin{array}{c}35-142 \\
142-435 \\
435-600\end{array}$ & $\begin{array}{c}68.22 \\
339.60 \\
552.20\end{array}$ & $\begin{array}{c}4.931(5.607) \\
22.003(20.716) \\
38.174(38.239) \\
35.438(35.358) \\
\end{array}$ & $\begin{array}{c}65.003 \\
(64.562)\end{array}$ & $\begin{array}{c}2 \mathrm{H}_{2} \mathrm{O} \\
\mathrm{C}_{9} \mathrm{H}_{11} \mathrm{~N} \\
\mathrm{C}_{13} \mathrm{H}_{12} \mathrm{~N}_{3} \mathrm{Cl} \\
\mathrm{C}_{7} \mathrm{H}_{4} \mathrm{CuN}_{2} \mathrm{O} 3 \\
\end{array}$ \\
\hline$[\mathrm{PdLCl}]$ & $\begin{array}{c}35-412 \\
412-600\end{array}$ & $\begin{array}{l}313.97 \\
497.47\end{array}$ & $\begin{array}{l}42.814(42.344) \\
44.124(41.19) \\
13.062(16.387)\end{array}$ & $\begin{array}{c}86.938 \\
(83.534)\end{array}$ & $\begin{array}{c}\mathrm{C}_{18} \mathrm{H}_{17} \mathrm{~N}_{3} \\
\mathrm{C}_{11} \mathrm{H}_{10} \mathrm{~N}_{3} \mathrm{O}_{2} \mathrm{Cl} \\
\mathrm{Pd}\end{array}$ \\
\hline$\left[\mathrm{PtLCl}_{3}\right]$ & $\begin{array}{c}45-145 \\
145-445 \\
445-598\end{array}$ & $\begin{array}{l}70.42 \\
357.8 \\
554.4\end{array}$ & $\begin{array}{c}4.931(4.902) \\
22.003(21.843) \\
47.166(47.417) \\
24.873(25.838)\end{array}$ & $\begin{array}{c}75.127 \\
(74.162)\end{array}$ & $\begin{array}{c}\mathrm{C}_{3} \mathrm{H}_{4} \\
\mathrm{C}_{9} \mathrm{~N}_{4} \mathrm{H}_{14} \\
\mathrm{Cl}_{3} \mathrm{C}_{16} \mathrm{~N}_{3} \mathrm{H}_{11} \\
\text { PtO }\end{array}$ \\
\hline
\end{tabular}


3.4. Kinetic study

Coats-Red fern is the method mentioned in the literature related to decomposition kinetics studies; this method is applied in this study ${ }^{29}$. From the TG curves, the activation energy, E, preexponential factor, A, entropies, $\Delta \mathrm{S}$, enthalpy, $\Delta H$, and Gibbs free energy, $\Delta \mathrm{G}$, were calculated by Coats-Redfern method; where:

$\Delta \mathrm{H}=\mathrm{E}-\mathrm{RT}$ and $\Delta \mathrm{G}=\Delta \mathrm{H}-\mathrm{T} \Delta \mathrm{S}$

The linearization curves of Coats-Red fern method. Kinetic parameters are calculated by employing the Coats- Red fern equations, are summarized in Table 5. The Coats-Red fern equation ${ }^{29}$ may be written in the form:

$\log \left[\frac{1-(1-\alpha)^{1-n}}{T^{2}(1-n)}\right]=\log \frac{\mathrm{ZR}}{\mathrm{qE}}\left[1-\frac{2 \mathrm{RT}}{\mathrm{E}}\right]-\frac{\mathrm{E}}{2.303 \mathrm{RT}}$ $\ldots . . n \neq 1 \ldots \ldots \ldots 1$ for complexes

$\log \cdot\left[\frac{-\log \cdot(1-\alpha) \cdot}{T^{2}}\right]=\log \cdot\left[\frac{A R}{\beta E}\left(1-\frac{2 R T}{E}\right]-\frac{E}{2.303 R T}\right.$

$\mathrm{n}=1 \ldots$ 2.for ligand where $\alpha$ is the mass loss at the completion of the reaction, $\mathrm{R}$ the gas constant, Ea the activation energy in $\mathrm{J} \mathrm{mol}^{-1}$ and $\mathrm{q}$ is the heating rate. Since 1-2 $\mathrm{RT} / \mathrm{Ea} \approx=1$, a plot of the left-hand side of the above equation against and $\Delta \mathrm{E}^{*}$ was calculated from the slope and A (Arrhenius constant) was found from the intercept. The activation entropy $\Delta \mathrm{S}^{*}$, the activation enthalpy $\Delta \mathrm{H}^{*}$ and the free energy of activation $\Delta \mathrm{G}^{*}$ were calculated using the following equations:

$$
\mathrm{S}^{*}=2: 303(\log \mathrm{Ah} / \mathrm{KT}) \mathrm{R} ; \quad \mathrm{H}^{*}=\mathrm{E}^{*}-\mathrm{RT} ; \quad \mathrm{G}^{*}=\mathrm{H}^{*}-\mathrm{T}_{\mathrm{S}} \mathrm{S}^{*}
$$

Where $\mathrm{K}$ and $\mathrm{h}$ are the Boltzmann's and Plank's constants, respectively. The calculated values of $\Delta \mathrm{E}^{*}, \Delta \mathrm{S}^{*}, \Delta \mathrm{H}^{*}$ and $\Delta \mathrm{G}^{*}$ for the dehydration and the decomposition steps are given in Table 5 . The activation energies of the decomposition were found to be in the range 134-208 $\mathrm{J} \mathrm{mol}^{-1}$. According to the kinetic data obtained from TGA curves, the negative values of activation entropies $\Delta \mathrm{S}^{*}$ indicate a more ordered activated complexes than the reactants and/or the reactions are slow ${ }^{30}$

Table 5. Thermodynamic parameters of the ligand and metal complexes.

\begin{tabular}{|c|c|c|c|c|c|c|c|c|c|c|}
\hline $\begin{array}{l}\text { Sam } \\
\text { (step) }\end{array}$ & $\begin{array}{l}\text { Trange } \\
{ }^{\circ} \mathrm{C}\end{array}$ & $\mathrm{n}$ & $\mathrm{R}^{2}$ & $\mathrm{~T}_{\max }{ }^{\mathrm{o}} \mathrm{K}$ & $\begin{array}{c}\mathrm{Ea} \\
\text { K.J mol }{ }^{-1}\end{array}$ & $\begin{array}{c}\Delta \mathrm{H}^{*} \\
\mathrm{KJ} \mathrm{mol}^{-1}\end{array}$ & $\mathrm{ASec}^{-1} \times 10^{5}$ & $\underset{\mathrm{J} \mathrm{mol}^{-1} \mathrm{~K}^{-1}}{\Delta \mathrm{S}^{*}}$ & $\begin{array}{c}\Delta \mathrm{G}^{*} \\
\mathrm{KJ} \mathrm{mol}^{-1}\end{array}$ & $\mathrm{~K} \times 10^{-6}$ \\
\hline $\mathrm{L}(1)$ & $158-348$ & 1 & 0.99 & 563.51 & 7.6669 & 2.982 & 425.5 & -104.171 & 61.983 & 1.7958 \\
\hline $\mathrm{L}(2)$ & $348-598$ & 1 & 0.99 & 786.85 & 12.2404 & 5.6986 & 830.9 & -101.378 & 85.467 & 2.1189 \\
\hline $\mathrm{CuL}_{=1}$ & $25-145$ & 0.9 & 0.97 & 341.37 & 4.57425 & 1.736 & 124.3 & -117.54 & 41.86 & 3.9316 \\
\hline $\mathrm{CuL}_{=2}$ & $145-435$ & 0.9 & 0.99 & 612.75 & 9.60396 & 4.509 & 479.0 & -103.878 & 68.160 & 15.4668 \\
\hline $\mathrm{CuL}_{=3}$ & 435- 600 & 0.9 & 0.99 & 825.35 & 12.68103 & 7.174 & 410.0 & -107.65 & 96.022 & 8.37053 \\
\hline $\mathrm{PdL}_{=1}$ & $35-412$ & 0.9 & 0.98 & 587.12 & 7.442325 & 2.56101 & 505.41 & -103.0818 & 68.4756 & 8.0847 \\
\hline $\mathrm{PdL}_{=2}$ & $412-600$ & 0.9 & 0.99 & 770.62 & 11.90189 & 5.49496 & 794.69 & -101.5799 & 83.77449 & 20.9573 \\
\hline Ni $L=1$ & $45-170$ & 0.9 & 0.99 & 348.5 & 6.609926 & 3.7215 & 1087.817 & -92.370 & 35.9035 & 41.5445 \\
\hline Ni $L=2$ & $170-355$ & 0.9 & 0.99 & 537.11 & 9.66478 & 5.19925 & 359.8129 & -105.167 & 61.6855 & 10.011818 \\
\hline Ni $L=3$ & $355-698$ & 0.9 & 0.99 & 750.53 & 16.21645 & 9.97655 & 646.665 & -103.074 & 87.336 & 8.3455 \\
\hline $\mathrm{CoL}=1$ & $45-150$ & 0.9 & 0.99 & 345.18 & 3.083122 & .2133 & 102.215 & -111.9558 & 38.8582 & 13.1695 \\
\hline $\mathrm{CoL}=2$ & $150-430$ & 0.9 & 0.99 & 632.54 & 10.34927 & 5.09033 & 497.5594 & -103.8282 & 70.7658 & 14.3221 \\
\hline $\mathrm{CoL}=3$ & $430-696$ & 0.9 & 0.99 & 750.06 & 14.9008 & 8.6648 & 648.66152 & -103.04 & 85.95 & 10.3317 \\
\hline $\mathrm{ptL}=1$ & $45-145$ & 0.9 & 0.99 & 341.37 & 5.792853 & 2.9547 & 146.04 & -108.8958 & 40.12847 & 7.2377 \\
\hline $\mathrm{ptL}_{=2}$ & $145-445$ & 0.9 & 0.99 & 632.75 & 12.11535 & 6.85467 & 477.78 & -104.1716 & 72.76927 & 9.8303 \\
\hline $\mathrm{ptL}_{=3}$ & $445-598$ & 0.9 & 0.99 & 827.55 & 12.7574 & 5.8772 & 936.7026 & -100.80124 & 96.17546 & 8.496 \\
\hline
\end{tabular}

3.5. Microbiological Investigation

The biological activity of ligand $\mathrm{L}$ and its complexes were tested against bacteria, we used more than one test organism to increase the chance of detecting antibiotic principles in tested materials. The organisms used in the present investigation included two Gram positive bacteria (Bacillus subtillis and Staphylococcus aureus) and two Gram negative bacteria (Escherichia coli and Pseudomonas aereuguinosa). The results of the bactericidal screening of the synthesized compounds are recorded in Table 6. An influence of the central ion of the complexes in the antibacterial activity against the tested Gram positive and Gram negative organisms show that the complexes have an enhanced activity compared to the ligands itself

Table 6. Antibacterial activity data of ligands and its complexes inhibition zone (mm).

\begin{tabular}{|c|c|c|c|c|}
\hline compound & $\begin{array}{c}\text { Bacillus } \\
\text { subtilis } \mathrm{G}^{+}\end{array}$ & $\begin{array}{l}\text { Staphylococcus } \\
\text { aureus } \mathrm{G}^{+}\end{array}$ & $\begin{array}{l}\text { Escherichia } \\
\text { Coli G- }\end{array}$ & $\begin{array}{l}\text { Pseudomonas } \\
\text { aeruginosa } \mathrm{G}^{-}\end{array}$ \\
\hline $\mathrm{L}$ & 20 & 17 & 19 & 16 \\
\hline$\left[\mathrm{CoL}\left(\mathrm{H}_{2} \mathrm{O}\right)_{2} \mathrm{Cl}\right]$ & 22 & 20 & 12 & 12 \\
\hline$\left[\mathrm{NiL}\left(\mathrm{H}_{2} \mathrm{O}\right)_{2} \mathrm{Cl}\right]$ & 24 & 23 & 15 & 14 \\
\hline$\left[\mathrm{CuL}\left(\mathrm{H}_{2} \mathrm{O}\right)_{2} \mathrm{Cl}\right]$ & 28 & 24 & 19 & 11 \\
\hline$[\mathrm{PdLCl}]$ & 22 & 24 & 12 & 17 \\
\hline$\left[\mathrm{PtLCl}_{3}\right]$ & 30 & 21 & 28 & 25 \\
\hline
\end{tabular}

Key to interpretation: less than $10 \mathrm{~mm}=$ inactive, $10-15 \mathrm{~mm}=$ weakly active, $15-20 \mathrm{~mm}=$ moderately active, more than $20 \mathrm{~mm}=$ highly active. 
3.6. Theoretical study

The vibration spectra of the A and Azo -Schiff base L was calculated by using a semi-empirical (PM3) method. The results obtained for wave numbers are presented in Table 7, and the comparisons with the experimental values indicate some deviations. These deviations may be due to the harmonic oscillator approximation and lack of electron correlation. It was reported Chamberlain, et al. that frequencies coupled with Hartree- Fock Theory (HFT) approximation and quantum harmonic oscillator approximations tend to be $10 \%$ too high $^{31,32}$.
3.6.1. Optimized Geometries Energy of metal complexes for A and AzoSchiff base

Theoretically probable structures of metal complexes with (A) and AzoSchiff base were calculated to search for the most probable model building stable structure, these shapes, show the calculated optima geometries for L and their metal complexes as shown in Figs. 1 and 2. The results of PM3 method of calculation in gas phase for the binding energies and heat of formation of $\mathrm{Co}(\mathrm{II}), \mathrm{Ni}(\mathrm{II}), \mathrm{Cu}(\mathrm{II})$ and $\mathrm{Pd}(\mathrm{II})$ complexes, are described in Table 7 and 8.

Table 7. Conformation energetic in $\left(\mathrm{K} \mathrm{J}_{\mathrm{M}} \mathrm{Mol}^{-1}\right)$ for the starting material (A), L and metal complexes.

\begin{tabular}{|c|c|c|}
\hline Conformation & $\Delta \mathrm{H}_{f}{ }^{\circ}$ & $\Delta \mathrm{E}_{\mathrm{b}}$ \\
\hline $\mathrm{A}$ & 143.0217934 & -5484.108206 \\
\hline $\mathrm{L}$ & 44.0793240 & -7227.2636760 \\
\hline $\mathrm{CoL}$ & -284.4905433 & -8081.4355433 \\
\hline $\mathrm{CuL}$ & -74.4882040 & -7849.7332040 \\
\hline $\mathrm{NiL}$ & -204.0042712 & -8001.3492712 \\
\hline $\mathrm{PdL}$ & 103.0683621 & -7353.9506379 \\
\hline
\end{tabular}

Table 8. Comparison of experimental and theoretical vibration frequencies for ligands

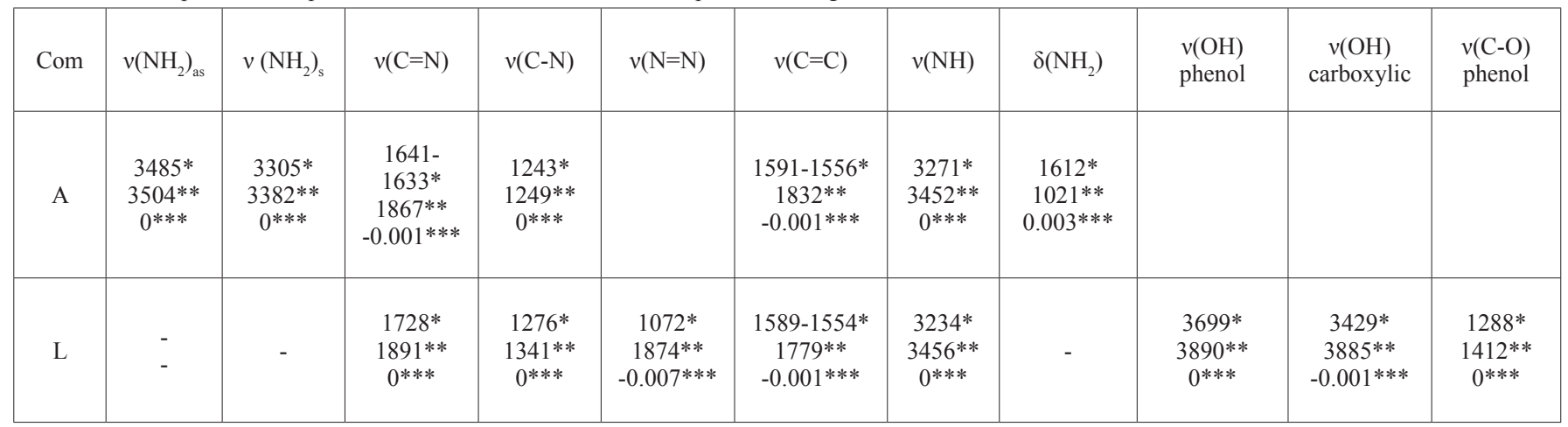

*: Experimental frequency, ${ }^{* *}:$ Theoretical frequency, ${ }^{* * *}:$ Error $\%$ due to main difference in the experimental measurements and theoretical treatments of vibration spectrum.

\subsubsection{Electrostatic Potential (E.P)}

Electron distribution governs the electrostic potential of molecules and describes the interaction of energy of the molecular system with a positive point charge, so it is useful for finding sites of reaction in a molecular positive charged species tend to attack a molecule where the E.P. is strongly negative electrophilic attach ${ }^{31}$. The E.P of free ligand was calculated and plotted as 2D contour to investigate the reactive sites of the molecules, and one can interpret the stereochemistry and rates of many reactions involving soft electrophiles and nucleophiles in terms of the properties of frontier orbitals (HOMO and LUMO). Overlap between the HOMO and LUMO values were plotted as $2 \mathrm{D}$ contour to get more information about these molecules. The results of calculation showed that the LUMO of transition metal ion prefers to react with the HOMO of nitrogen atoms of Azo- Schiff base ligand as shown in Fig. 3.

\section{CONCLUSION}

New $\mathrm{Co}^{\mathrm{II}}, \mathrm{Ni}^{\mathrm{II}}, \mathrm{Cu}^{\mathrm{II}}, \mathrm{Pd}^{\mathrm{II}}$ and $\mathrm{Pt}^{\mathrm{II}}$ metal complexes with Azo-Schiff base derived $\mathrm{L}_{1}$ from reaction $m$-hydroxy benzoic acid with 1,5-Dimethyl-3-[2(5-methyl-1 $H$-indol-3-yl)-ethylimino]-2-phenyl-2,3-dihydro-1 $H$-pyrazol-4ylamine have been synthesized. All the complexes are insoluble in water but soluble in DMF, as well as all of them are non-electrolyte. The structure of the complexes based on Uv-Vis, IR, mass spectroscopy were proposed that the
Azo-Schiff base Ligand $\mathrm{L}$ behave as tridentate which coordinated with the metal ions through N, N, O atoms. It can be suggested that the geometry of the Co(II), $\mathrm{Ni}(\mathrm{II})$ and $\mathrm{Cu}(\mathrm{II})$ have octahedral geometry as shown in Fig. 4, $\mathrm{Pd}(\mathrm{II})$ and $\mathrm{Pt}(\mathrm{II})$ complexes have square planer geometry as shown in Fig. 5 (a and b).Hyper Chem-8 program was used to predict structural geometries of compounds in gas phase. The heat of formation $\left(\Delta \mathrm{H} f^{\circ}\right)$ and binding energy $(\Delta \mathrm{Eb})$ at $298^{\circ} \mathrm{K}$ for the free ligands and its vanadyl complexes was calculated by PM3 method. The synthesized ligands and its metal complexes were screened for their biological activity against bacterial species, two Gram positive bacteria (Bacillus subtillis and Staphylococcus aureus) and two Gram negative bacteria (Escherichia coli and Pseudomonas aereuguinos 

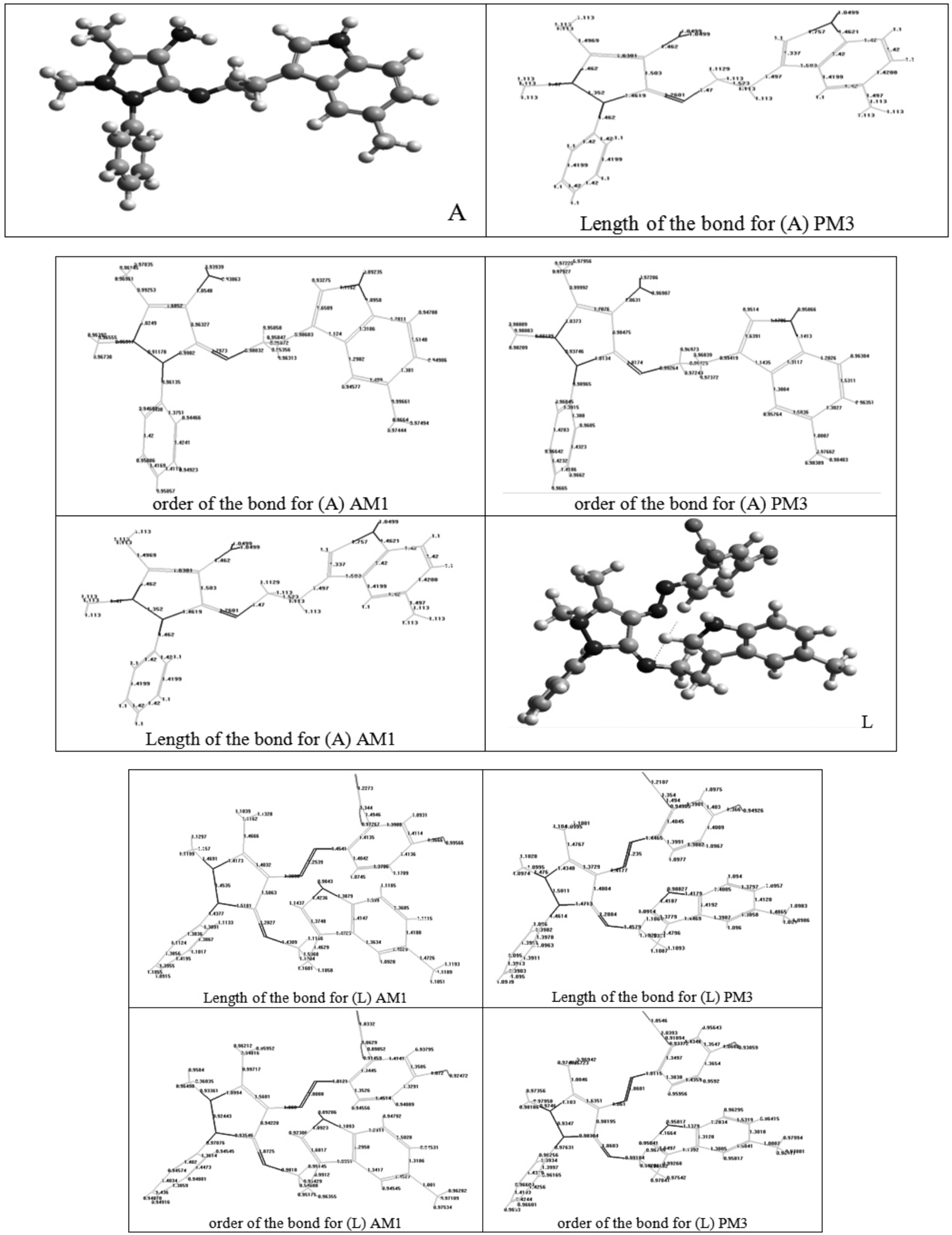

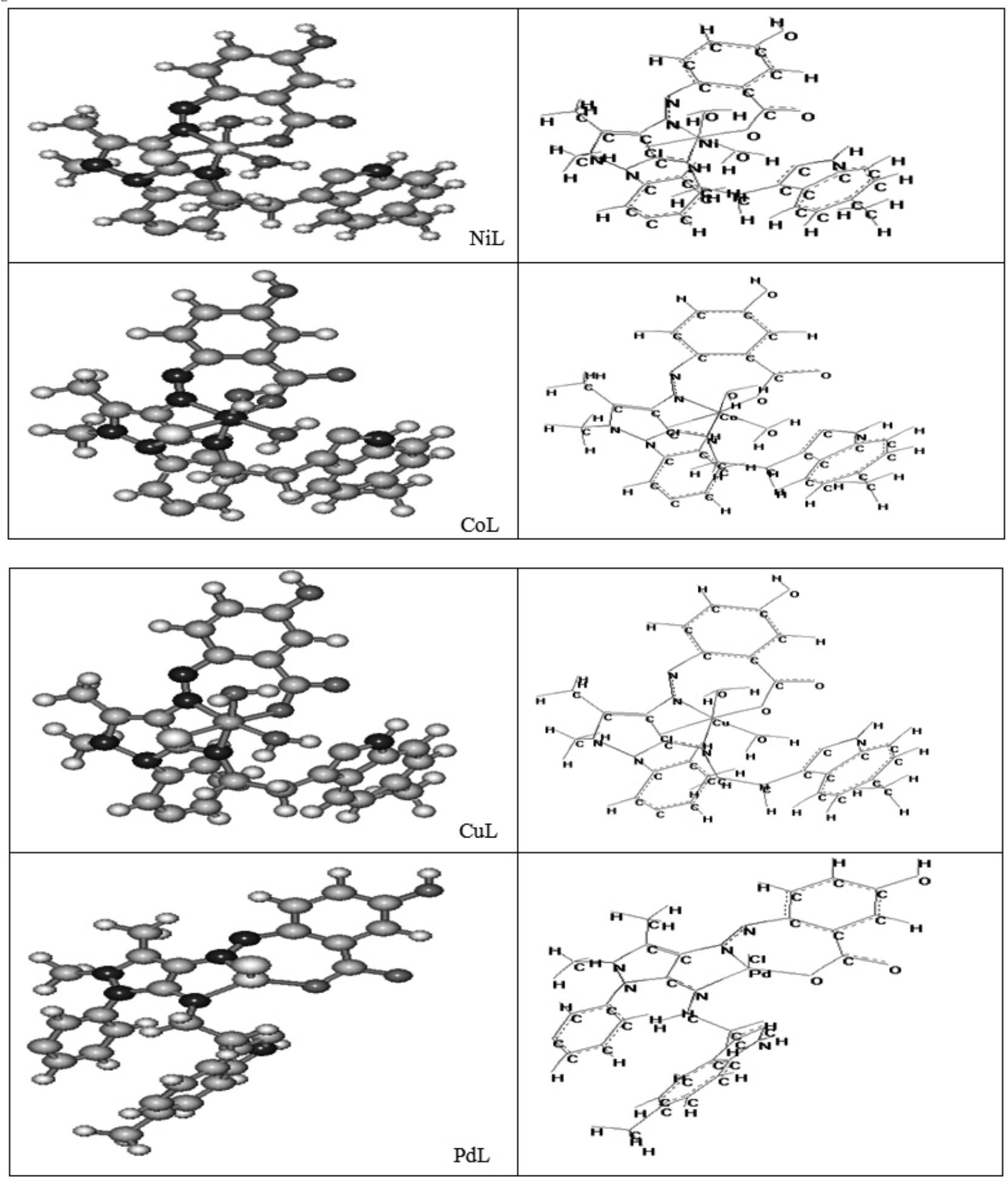

Fig.1. Conformational Structure of A, ligand and their Complexes 

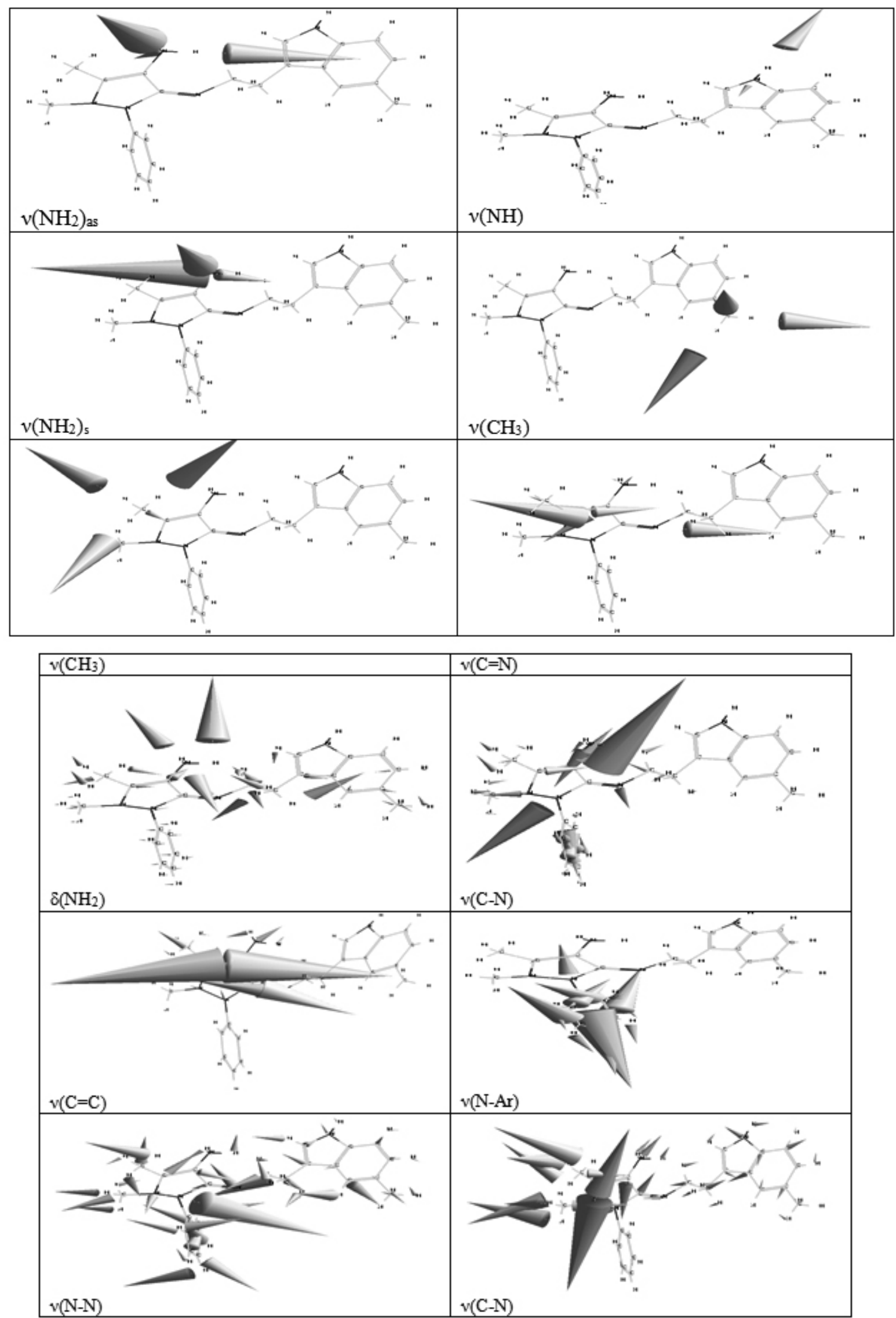

(b) 

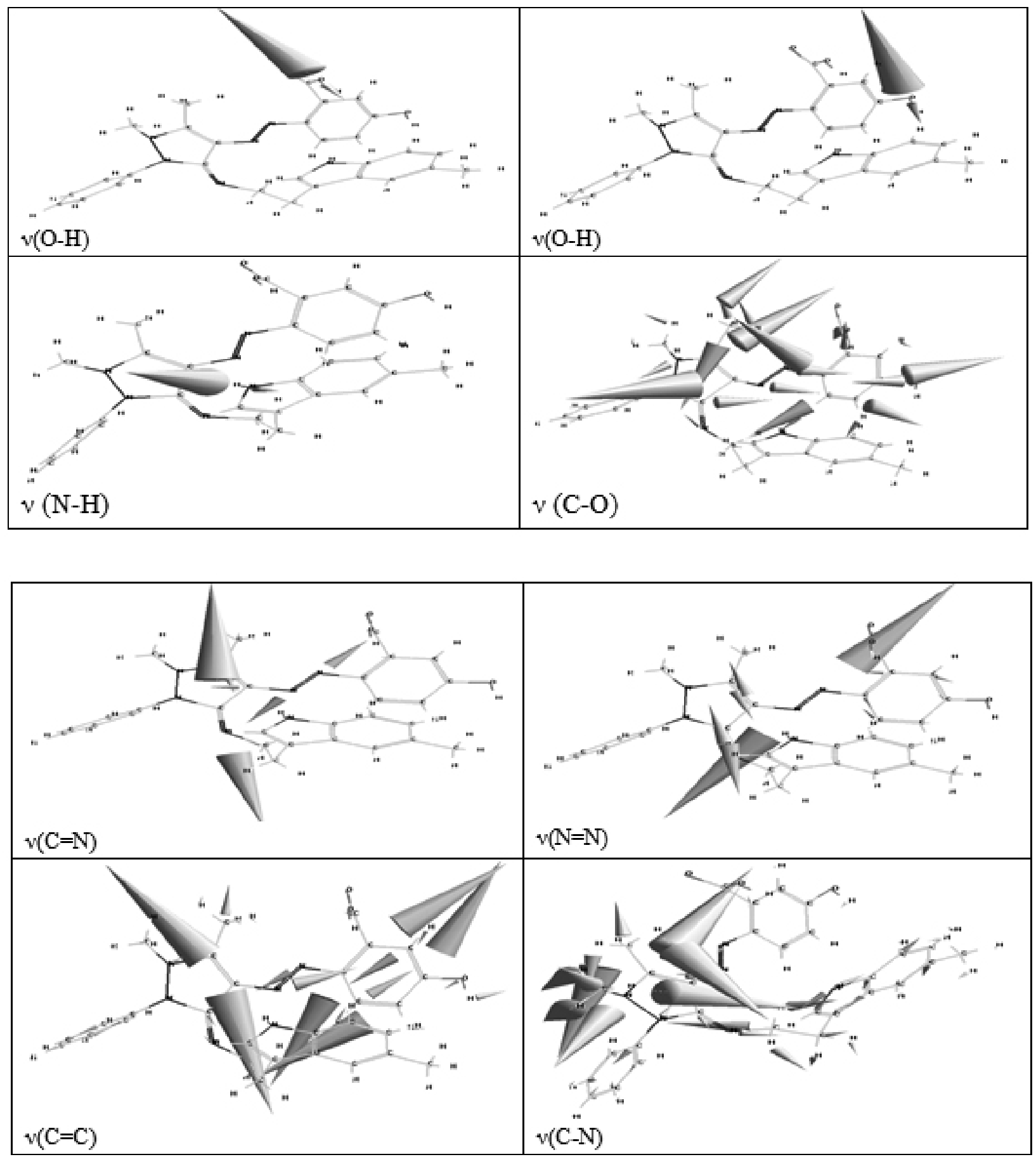

Fig. 2. The calculated vibrational frequencies of starting material A(a) and ligand L (b) 

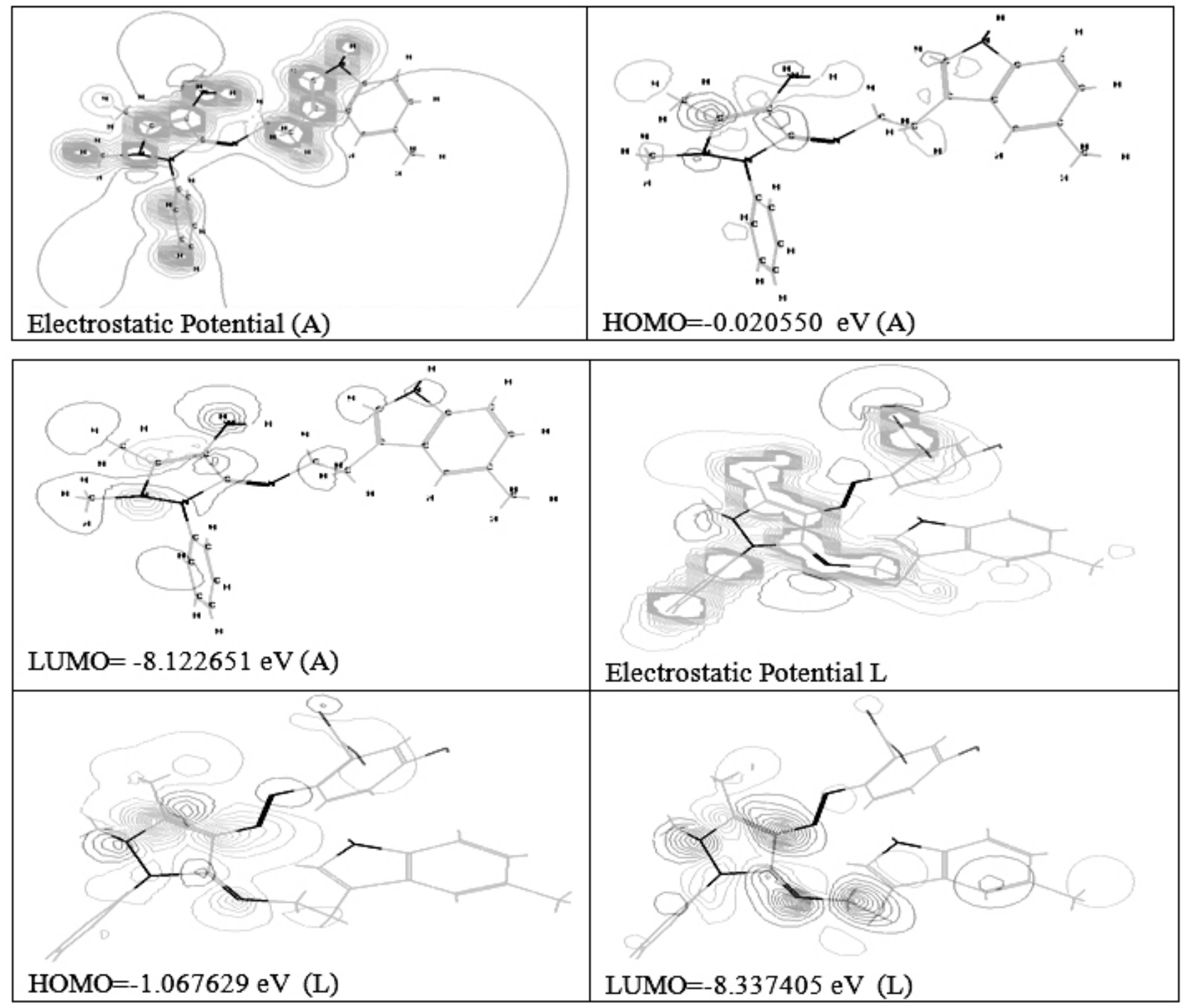

Fig. 3. HOMO and Electrostatic Potential as for starting material and L

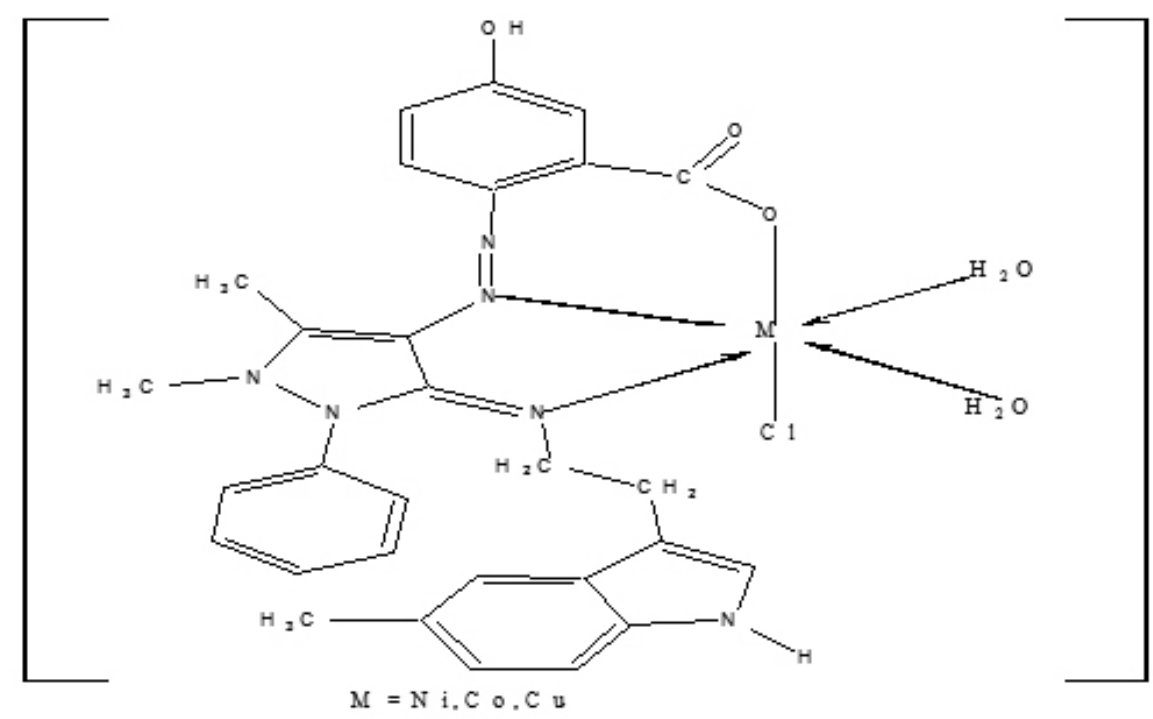

Fig.4. Structure of octahedral complexes 

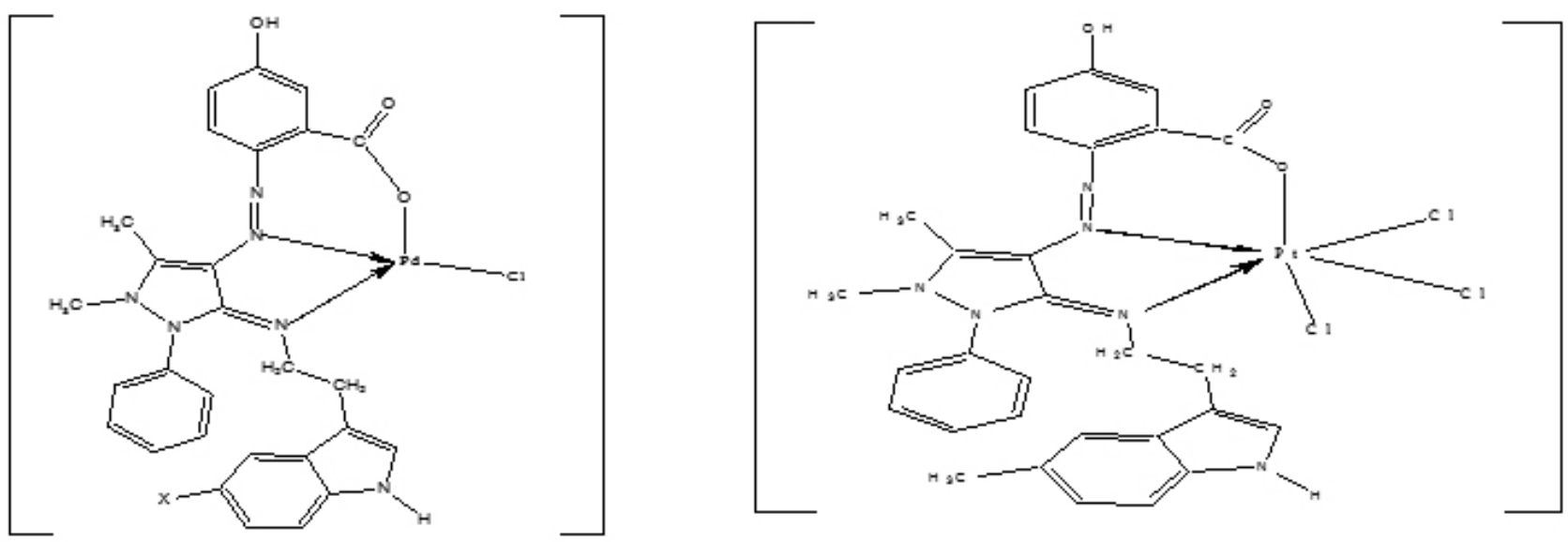

Fig.5. (a) Structure of the $\left[\mathrm{PtLCl}_{3}\right]$ complex and (b) Structure of the $[\mathrm{PdLCl}]$ complex

\section{REFERENCES}

1. A. A. Khandar, K. Nejati, Polyhedron, 19, 607-613 (2000).

2. N. Kamellia, Z. Rezvani, B. Massoumi, Dyes and Pigments, 75, 653-657 (2007).

3. M. S. Refat, M. E. Ibrahim, K. I. Hassan, E. G. Samir, Spectrochimica Acta Part A, 65, 1208-1220 (2006).

4. F. D. Karia, P. H. Parsania, Asian J. Chem. Soc., 11, 3, 991 (1999).

5. P. G. More, R. B. Bhalvankar, S. C. Pattar, J. Indian Chem. Soc., 78, 9, 474 (2001).

6. A. H. Elmasry, H. H. fahmy, S. H. A. Abdel wahed, Molecules, 5, 1429 (2000).

7. M. A. Baseer, V. D. Jadhav, R. M. Phule, Y. V. Archana, Y. B. Vibhute, Orient. J. Chem., 16, 3, 533 (2000).

8. S. N. Pandeya, D. Sriram, G. Nath, E. Declercq, Il Farmaco, 54, 624 (1999).

9. W. M. Singh, B. C. Dash, Pesticides, 22, 33 (1988).

10. E. M. Hodnett, W. J. Dunn, J. Med. Chem., 13, 768 (1970).

11. S. B. Desai, P. B. Desai, K. R. Desai, Heterocycle Commun., 7, 1, 83 (2001).

12. P. Pathak, V. S. Jolly, K. P. Sharma, Orient. J. Chem., 16, 1, 161 (2000).

13. E. Halabieh, O. Mermut, B. Christopher, J. Pure Appl Chem., 76, 1445 (2004).

14. H. Nishihara, Bull Chem Soc. Jpn, 77, 407 (2004)

15. A. Samir, F. E. Hanan, A. Dahshan, Journal of Molecular Structure, 983, 32-38 (2010).

16. K. Mini, M. R. Prathapachandra and E. Suresh, polyhedron, 26 (2007), 2713-2718.

17. A. Golcu, M. Tumer, H. Demirelli, R. A. Wheatley, Inorg. Chim. Acta, 358, $1785(2005)$

18. S. A. Shaker ${ }^{\mathrm{a}}$, E-Journal of Chemistry, 7, S1, S580-S586 (2010).

19. S. A. Shaker ${ }^{\mathrm{b}}$, E-Journal of Chemistry, 8, 1, 153-158 (2011).

20. A. B. P. Lever, Inorganic Electronic Spectroscopy, Elsevier publishing Co. Ltd: New York, 1968.

21. S. A. Shakerc, Yang Farina, American Journal of Scientific Research, ISSN 1450-223X, 5, 20-26 (2009).

22. H. E. C. Mun, A. C. Karen, I. M. T. Mohammed, R. Rozita, U. T. Nasir and R. C. Andrew, Polyhedron, 27, 4, 1141-1149 (2008).

23. S. A. Shaker ${ }^{d}$ E-Journal of Chemistry, 7, 4, 1598-1604 (2010).

24. S. A. Shaker ${ }^{\mathrm{e}}$, H. Khaledi, H. M. Ali, Chemical Papers, 65, 3, 299-307 (2011).

25. A. A. Salah, J. Um-Salama for Science, 2, 395-602 (2005).

26. R. M. Silverstein, G. C. Bassler, T. C. Morril, Spectroscopic Identification of Organic Compounds, Wiely: New York, $4^{\text {th }}$ edn., 1981.

27. N. S. Ravichandran and C. Thangaraja, J. Chem. Sci, 116, 215-219 (2004).

28. K. M. Nakamoto, Infrared and Raman Spectra of Inorganic and Coordination Compounds, Wiely-Inter Science: New York, 1997.

29. A.W. Coats, J.P. Redfern, Nature, 68, 201 (1964).
30. A. A. Frost, R.G. Pearson, Kinetics and Mechanism, Wiley: New York, 1961.

31. H. Druckerey, H. F. Mark, Benzene Diazonium Salts-Azo Dyes, 1, 123 (2006).

32. B. M. Chamberlain, Y. Sun, J. R. Hagadorn, E. W. Hemmesch, A. V. Hillmyer, W. B. Tolman, Macrollecules, 32, 2400 (1999). 